\title{
LOKALNA VODOOSKRBA NA KRASU
}

\author{
dr. Nataša Ravbar \\ Inštitut za raziskovanje krasa ZRC SAZU \\ Titov trg 2, SI-6230 Postojna \\ e-mail: natasa.ravbar@zrc-sazu.si
}

Pregledni znanstveni članek

COBISS 1.02

\section{Izvleček}

Številni kraški izviri predstavljajo pomembne lokalne vire pitne vode, ki pokrivajo skoraj polovico državnih potreb. Prispevek obravnava način vodooskrbe v preteklosti ter današnje stanje, težave in izzive, s katerimi se soočamo. Kakovost kraških vodnih virov je zadovoljiva, predstavljene raziskave pa prikazujejo, da je stopnja zaščite njihovih prispevnih območij neprimerna. Dodatno so zaradi nesmotrne porabe vode ogrožene razpoložljive količine vodnih zalog. Za ohranjanje našega največjega rezervoarja kakovostne pitne vode morajo načrti za lokalno vodooskrbo temeljiti na ustreznih strokovnih raziskavah, kot jih predstavlja pričujoči članek.

Ključne besede: pitna voda, kras, kraški vodni viri, vodooskrba, upravljanje z vodnimi viri, odnos do pitne vode

\section{LOCAL DRINKING WATER SUPPLY IN KARST REGIONS}

\begin{abstract}
Numerous karst springs are important resources of local drinking water supply, covering almost half of the country's needs. This paper discusses water supply in the past and today, problems and challenges that it is facing. The quality of karst water sources is good, however, the presented researches show that the protection of catchment areas has so far been insufficient. Due to uneconomical use, the available quantities of water resources are also threatened. To keep our biggest reservoir of qualitative drinking water safe, further planning of water supply will need to base on appropriate research, as are the presented ones.
\end{abstract}

Key words: drinking water, karst, karst water sources, water supply, water sources management, attitude towards drinking water 


\section{UVOD}

Neonesnažena voda je naravna dobrina, ki je pogoj za življenje različnih ekosistemov in človeka na našem planetu. V mnogih državah se že soočajo s pomanjkanjem vode, še posebej čiste pitne, in njen status strateške surovine že sproža prve vojne. Emisije nevarnih snovi, ki jih človek posredno ali neposredno spušča v okolje, poslabšujejo kakovost voda in zmanjšujejo primernost vodnih virov za uporabo. Grožnja klimatskih sprememb in nenehno naraščanje števila prebivalstva pa lahko ob dosedanjem odnosu do pitne vode pripeljeta celo do velike svetovne krize.

Gostota rečne mreže v Sloveniji je zelo visoka in znaša kar $1,33 \mathrm{~km} / \mathrm{km}^{2}$ (Kolbezen in Pristov 1998), v geoloških enotah, ki lahko prevajajo in akumulirajo podzemno vodo, pa je razpoložljive okoli $1,43 \times 10^{9} \mathrm{~m}^{3}$ vode letno (Andjelov in sod. 2006). Slovenija je torej bogata $\mathrm{z}$ vodami, toda le-te niso enakomerno prostorsko razporejene. Največje zaloge vode pri nas so podtalnice $\mathrm{v}$ prodnih ravninah, vendar je ponekod njihova kakovost okrnjena (npr. na Ljubljanskem, Ptujskem polju). Znatno upadanje vodnih zalog v nekaterih slovenskih medzrnskih vodonosnikih pa zmanjšuje izrabo teh vodnih virov.

Za vodooskrbo so v Sloveniji izjemnega pomena kraški izviri. Ocene virov vodooskrbe v Sloveniji kažejo, da okoli polovico potreb po pitni vodi pri nas pokrivamo iz kraških vodnih virov, ob suši pa kraška voda sestavlja celo dve tretjini vodnih zalog (Brečko Grubar in Plut 2001). V primerjavi z nekaterimi drugimi državami v Evropi smo v tem pogledu skupaj $\mathrm{z}$ Avstrijo na samem vrhu (Zwahlen 2004).

Najbolj izdatni kraški vodni viri so npr. Rižana, Mrzlek, Hubelj, Vipava, Malni, Bistrica, Rakitnica, Dobličica, itd., ki oskrbujejo ogromna območja na zahodu, jugozahodu, jugu in jugovzhodu države. V alpskem svetu večji kraški izviri napajajo Sočo, Koritnico, Krajcarico, Zadlaščico, Tolminko ter Savo Bohinjko in Dolinko (Ravbar in Kovačič 2006).

Zaradi velikega pomena kraških vodnih virov je v prispevku predstavljen pregled zgodovinskega razvoja in današnje stanje lokalne vodne oskrbe iz kraških vodonosnikov. V nadaljevanju so izpostavljene težave in izzivi, s katerimi se sooča sodobna vodooskrba, kot je pomanjkljiva zaščita vodnih virov ter negospodaren in malomaren odnos posameznikov do pitne vode. Prikazani izsledki predstavljajo dobro podlago pri oblikovanju temeljnih načrtov za učinkovitejše načrtovanje vodooskrbe ter za previdno upravljanje $\mathrm{z}$ vodnimi viri v prihodnosti.

\section{OSKRBA S PITNO VODO NA KRASU V PRETEKLOSTI}

Na krasu sta bila za življenje in gospodarski razvoj nekdaj največja omejitvena dejavnika oskrba z zadostnimi količinami kvalitetne pitne vode ter pomanjkanje primernih obdelovalnih površin. Kraška območja so pri nas sicer dobro namočena s padavinami prek celega leta, vendar se hitro infiltrirajo skozi propustna, apnenčasta tla in površinski tokovi so zato redki. Voda se večinoma pretaka podzemsko, na stiku z nepropustnimi kamninami pa zopet pride na dan v obliki močnih izvirov visoke kakovosti in s stabilnimi vodostaji prek celega leta.

Zato je v kraških pokrajinah človek za vodooskrbo nekoč najlažje izkoriščal izvire (slika 1). Da so prišli do vode, so iz oddaljenih krajev hodili tudi po več kot deset kilometrov, kar je 
Slika 1: Odjemi vode iz Rižane segajo v zgodnje 19. st., ko je bila dolina Rižane žitnica Trsta. Leta 1935 je bil zgrajen obalni vodovodni sistem z zajetjem njenega izvira, ki je takrat oskrboval vsa večja obalna mesta (foto: N. Ravbar)

Figure 1: The water from Rižana river was taken away in the beginning of 19th century, when Rižana valley has been granary of Triest. In the year 1935 coastal water supply system for coastal towns was built, taking water from Rižana river. (photo: N. Ravbar)

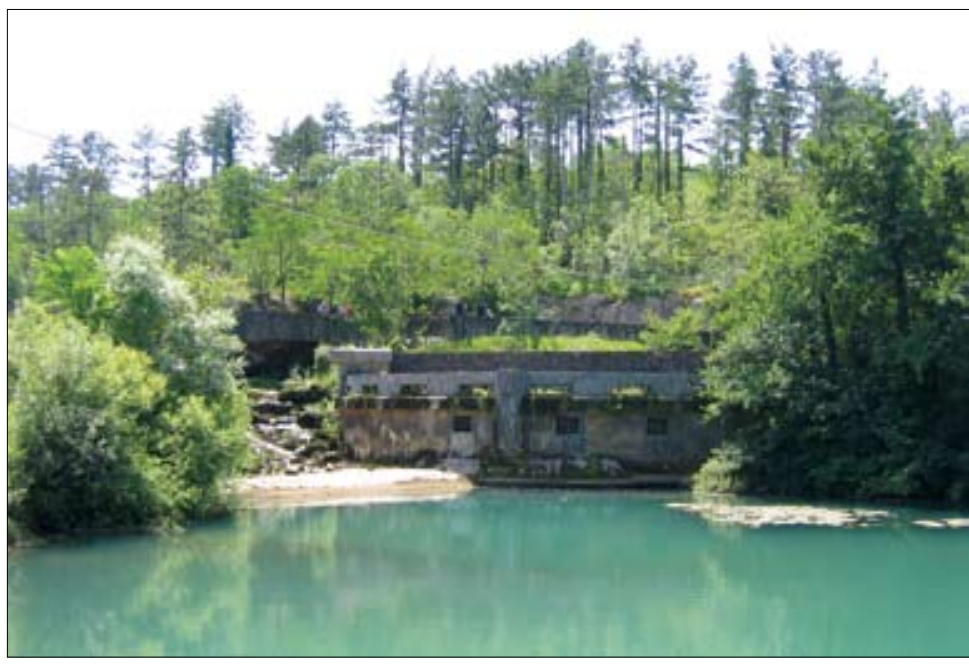

Slika 2: Na kraškem svetu, kjer površinskih tekočih voda ni, je glavni vir oskrbe z vodo temeljil na stekanju kapnice, ki so jo zbirali v štirnah (foto: N. Ravbar)

Figure 2: Collecting rainwater in wells was the most important way of water supply in karst regions. (photo: N. Ravbar)

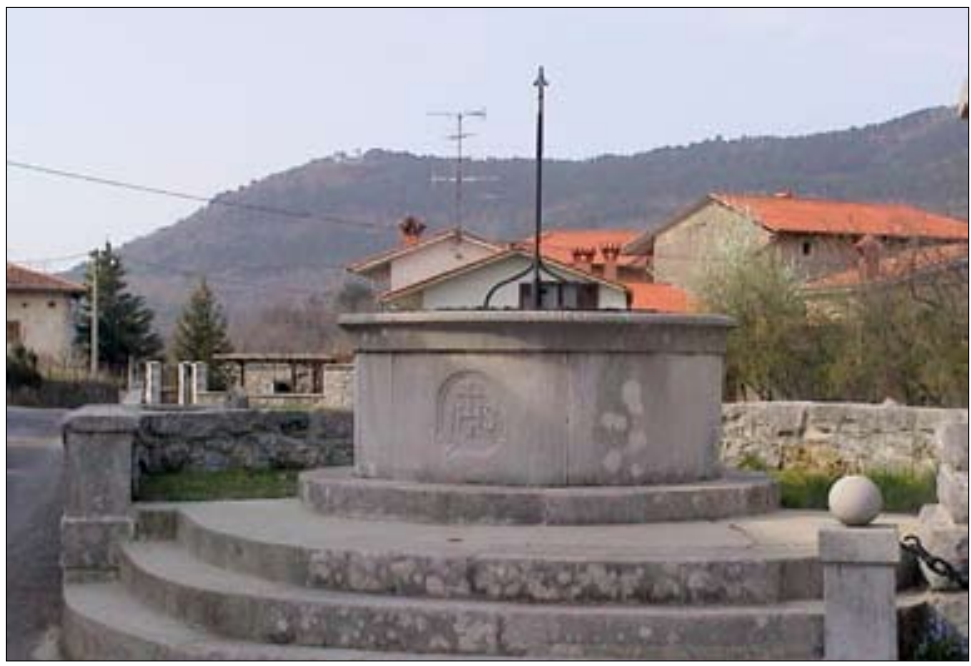


terjalo več ur (Zupančič 1988). Izvirov pa niso uporabljali le za pitno vodo, temveč so njihovo energijo izkoriščali tudi za mline, kovačnice in žage.

Na obsežnih kraških planotah, kjer površinskih tekočih voda ni, je glavni vir oskrbe z vodo temeljil na stekanju kapnice, ki so jo zbirali v štirnah in lokvah (slika 2), živino pa so napajali v zato posebej narejenih kalih. Za oskrbo s pitno vodo so si nekdaj domačini pomagali tudi na več drugih načinov; s taljenjem ledu iz ledenih jam in snega v zimskem času, stekanjem iz okoliških studencev in podobno (slika 3). Štirne, ledenice, lokve in kali so ponekod še vedno ohranjeni ali prenovljeni, vendar povečini ostajajo spomenik nekdanjemu času.

Slika 3: Prvo vodovodno omrežje na Krasu je bilo zgrajeno za potrebe Južne železnice. V Gornjih Ležečah v Košanski dolini so vodo pridobivali iz okoliških studencev z nekraškega sveta. Vdveh zbiralnikih je bilo mogoče zbrati do $22.000 \mathrm{~m}^{3}$ vode (foto: $N$. Ravbar)

Figure 3: The first water supply system on Karst region was built for a need of South railway (Vienna-Triest). In Gornje Ležeče village in Košana valley, the water was taken from the springs, flowing from non-karst area. Two reservoirs contain $22.000 \mathrm{~m}^{3}$ of water (photo: $N$. Ravbar)

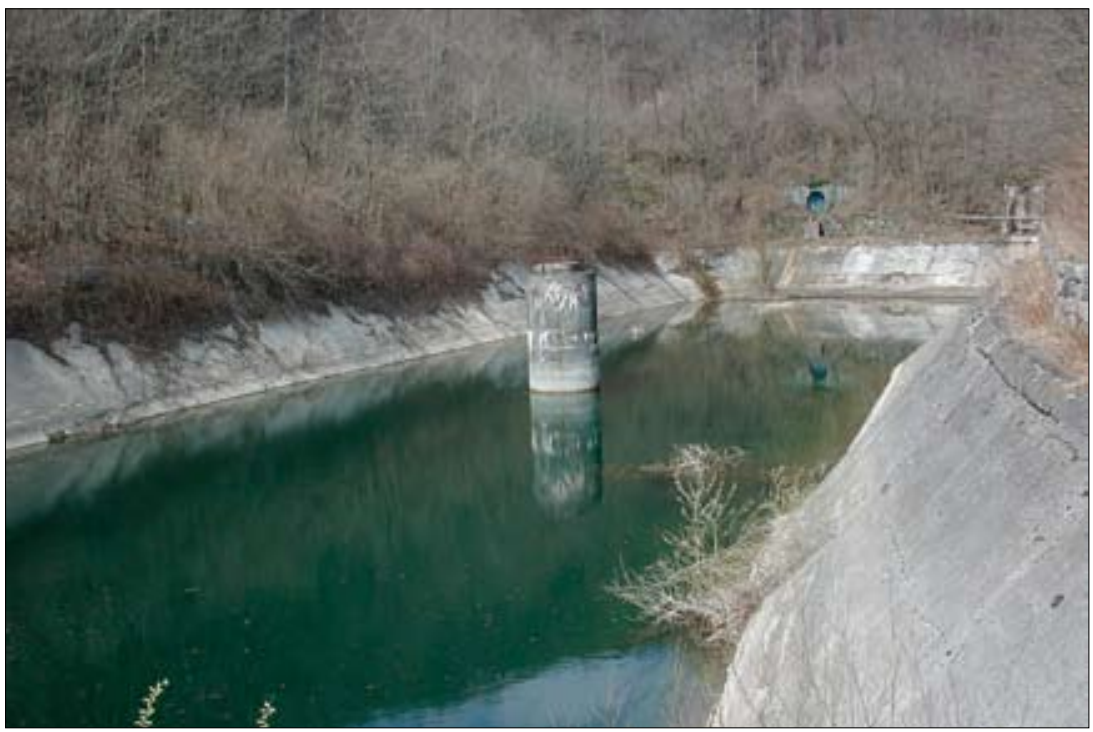

\section{SODOBNA VODOOSKRBA}

$\mathrm{S}$ tehnološkim razvojem je preskrba $\mathrm{z}$ vodo postopoma postala precej urejena in je danes zagotovljena številnim gospodinjstvom tudi na odročnih območjih. Najpreprostejši način odvzema vode je zajetje na izviru, ob premajhni izdatnosti pa lahko dodatne količine vode pridobimo s črpanjem (slika 4). Vodooskrba temelji večinoma na stalnih in izdatnih vodnih virih (preglednica 1), nekdanji vodni viri z zajemanjem skromnih količin površinske, podzemne in padavinske vode pa so že skoraj povsem izgubili svoj pomen. 
Slika 4: Iz črpališča Klariči se z vodo oskrbuje pet kraških občin, vodo pa oddajajo tudi obalnim občinam (foto: N. Ravbar)

Figure 4: Five municipalities on karst region and part of coastal area are supplied by water from Klariči water pump station (photo: N. Ravbar)

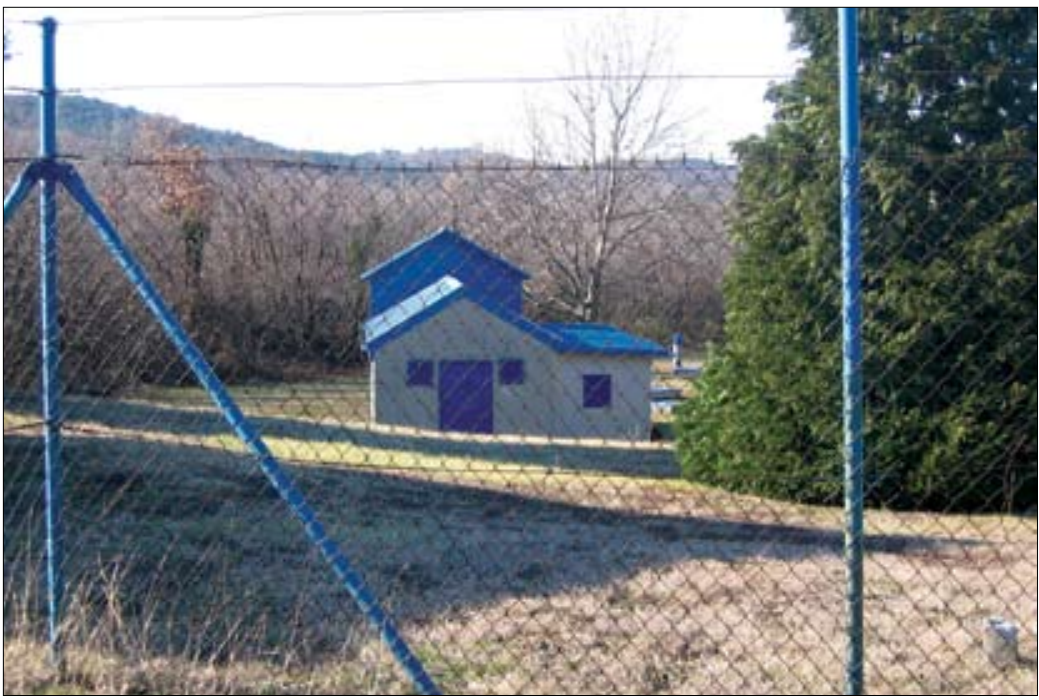

Slika 5: Zaloge izvirov Malenščice so zelo velike, a zaradi velikega obsega zaledja je visoka tudi njihova ogroženost (foto: $M$. Petrič)

Figure 5: Water capacity of Malenščice spring is very great, but large hinterland is a threat of pollution (photo: M. Petrič)

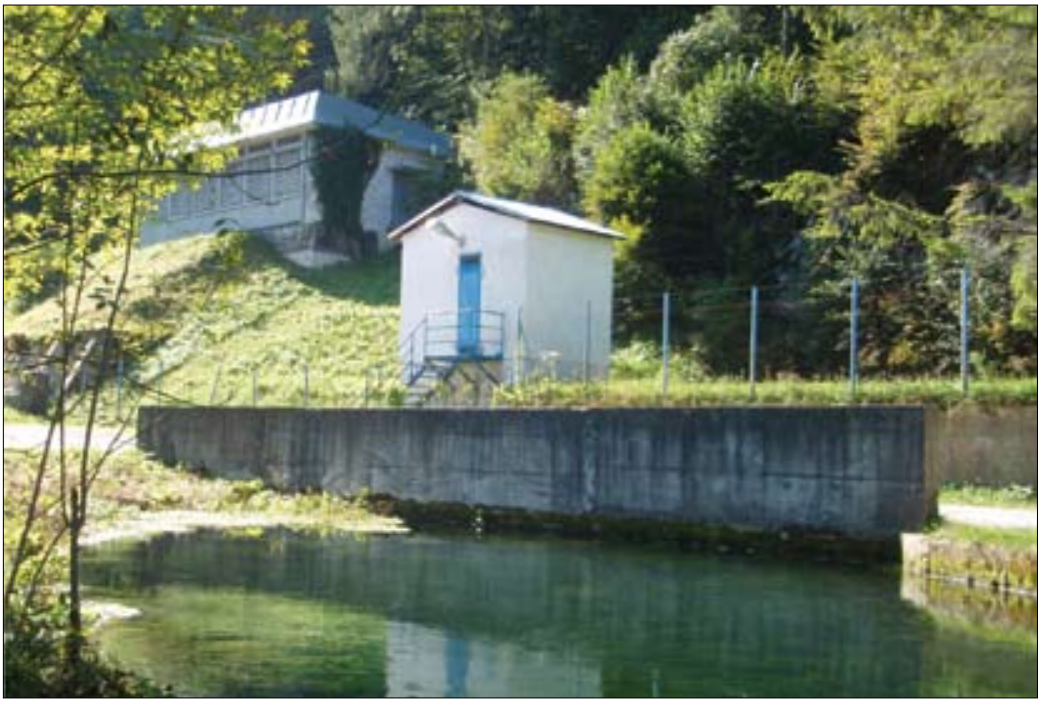


Prednost velikih kraških izvirov so zadostne količine vode, zaradi velikega napajalnega zaledja pa je težko varovati njihovo kakovost (slika 5). Navadno je neko območje vezano na oskrbo iz samo enega vodnega vira v bližnji okolici (slika 6). Ob suši ali onesnaženju lahko to območje ostane brez pitne vode, oziroma je njena kakovost omejena in oskrba motena (Petrič in Ravbar 2008).

Kakovost vodnih zalog je v slovenskem krasu še relativno visoka, čeprav je trenutna stopnja zaščite vodnih virov in njihovih prispevnih območij nezadovoljiva. Vzroki so povezani z zmešnjavo na zakonodajnem področju, navzkrižnih interesih različnih uporabnikov prostora, pogosto neučinkovitim nadzorom nad kršitelji določil in s pomanjkanjem znanja o trajnostnem ravnanju $\mathrm{z}$ vodnimi viri. Poleg tega zaradi populacijske in gospodarske rasti ter številnih drugih socialno-ekonomskih procesov potreba po pitni vodi vse bolj narašča (Bricelj in Rejec Brancelj 1990; Richter-Jakob 2005), odnos do nje pa je negospodaren in malomaren.

Slika 6: Skica lokalne vodovodne mreže, ki s pitno vodo oskrbuje prebivalce Suhe krajine in dolino Krke.

Figure 6: Sketch of Suha krajina region and Krka valley local water supply network.

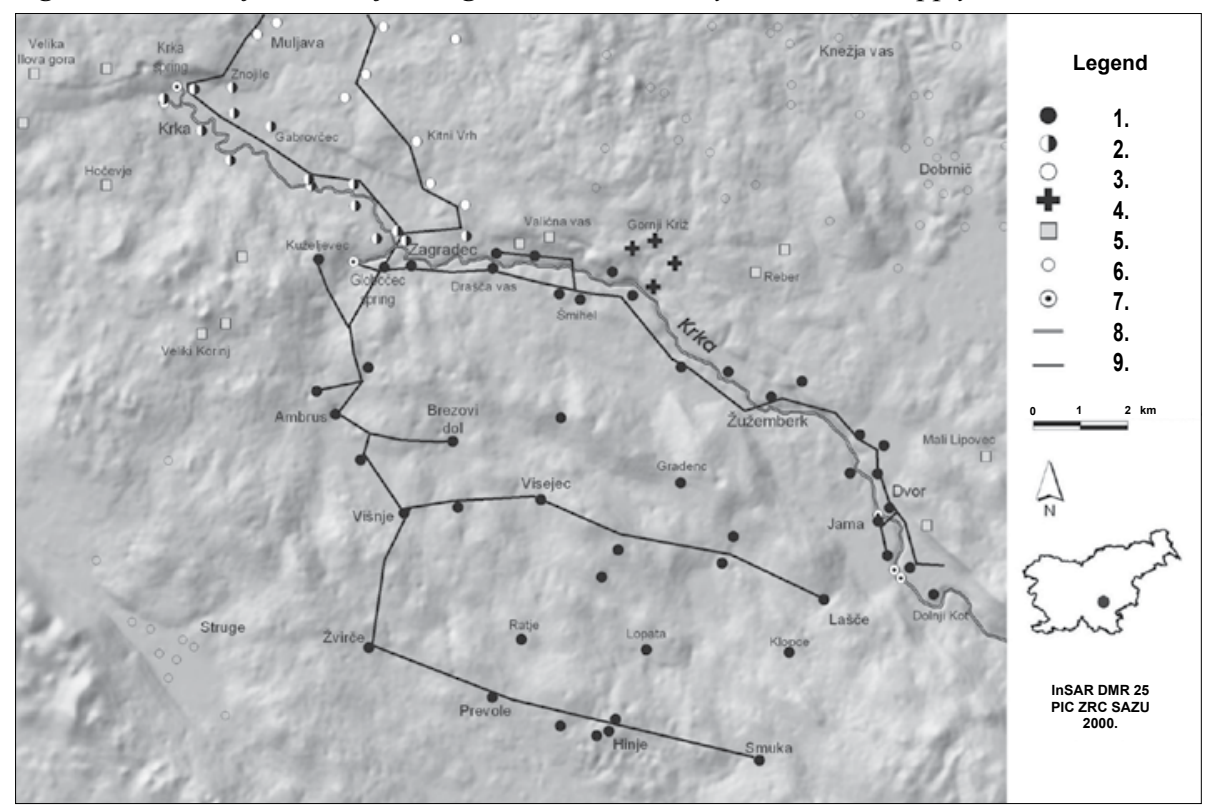

Legenda/Legend: 1. kraji, ki se oskrbujejo le iz vodnega vira Globočec (villages with water supply from Globočec spring only), 2. kraji, ki se oskrbujejo iz vodnih virov Globočec in Stiški potok (villages with water supply from Globočec spring and Stiški potok), 3. kraji, ki se oskrbujejo le iz vodnega vira Stiški potok (villages with water supply from Stiški potok only), 4. kraji, ki se oskrbujejo iz lokalne vrtine (villages with water supply from local well), 5. kraji, ki se oskrbujejo s kapnico (villages with rainwater supply), 6. druga naselja (other villages), 7. kraški izvir (karst spring), 8. površinski tok (brook, river), 9. primarno vodovodno omrežje v Suhi krajini in dolini Krke (primary water supply network in Suha krajina region and Krka valley) 
Preglednica 1: Osnovni podatki o črpanju in lokalni oskrbi prebivalcev s pitno vodo v Sloveniji iz izbranih vodnih virov

Table 1: Basic data on used water sources and local water supply in Slovenia from selected water sources

\begin{tabular}{|c|c|c|c|c|c|c|}
\hline $\begin{array}{l}\text { Vodovodni } \\
\text { sistem }\end{array}$ & Vodni vir & $\begin{array}{r}\text { Tip } \\
\text { vodo- } \\
\text { nosnika }\end{array}$ & $\begin{array}{r}\text { Povprečna } \\
\text { količina } \\
\text { načrpane } \\
\text { vode }(\mathrm{v} l / s)\end{array}$ & $\begin{array}{r}\text { Št. preb., } \\
\text { ki jih } \\
\text { vodovodni } \\
\text { sistem } \\
\text { oskrbuje }\end{array}$ & $\begin{array}{r}\text { Povprečna } \\
\text { poraba vode (v } \\
\mathrm{m}^{3} / \text { leto) }\end{array}$ & $\begin{array}{r}\text { Dolžina } \\
\text { vodovodnega } \\
\text { sistema }\end{array}$ \\
\hline $\begin{array}{l}\text { Rižanski } \\
\text { vodovod } \\
\text { Koper }\end{array}$ & Rižana & kraški & 240 & $\begin{array}{r}\text { Od } 80.000 \\
\text { do } 100.000 \\
\text { v turistični } \\
\text { sezoni }\end{array}$ & 6,1 milijona & $920 \mathrm{~km}$ \\
\hline $\begin{array}{l}\text { Kraški } \\
\text { vodovod } \\
\text { Sežana }\end{array}$ & $\begin{array}{r}\text { Klariči } \\
\text { (vrtine), } \\
\text { izviri izpod } \\
\text { Nanosa }\end{array}$ & $\begin{array}{l}\text { kraški } \\
\text { kraški }\end{array}$ & $\begin{array}{r}50 \\
3-30\end{array}$ & 20.000 & 1,2 milijona & $480 \mathrm{~km}$ \\
\hline $\begin{array}{l}\text { Kovod } \\
\text { Postojna }\end{array}$ & $\begin{array}{r}\text { Malni, } \\
\text { Nanoški } \\
\text { izviri, }\end{array}$ & $\begin{array}{l}\text { kraški } \\
\text { kraški }\end{array}$ & $\begin{array}{r}90 \\
9,5\end{array}$ & 18.000 & 1,4 milijona & $300 \mathrm{~km}$ \\
\hline $\begin{array}{l}\text { Goriški } \\
\text { vodovodi }\end{array}$ & $\begin{array}{r}\text { Hubelj, } \\
\text { Mrzlek, } \\
\text { Kromberk }\end{array}$ & $\begin{array}{l}\text { kraški } \\
\text { kraški } \\
\text { kraški }\end{array}$ & $\begin{array}{r}100 \\
250 \\
20\end{array}$ & 54.300 & 4,2 milijona & $450 \mathrm{~km}$ \\
\hline $\begin{array}{l}\text { Suha krajina } \\
\text { in dolina Krke }\end{array}$ & Globočec & kraški & 16 & 4700 & 375.000 & $180 \mathrm{~km}$ \\
\hline $\begin{array}{l}\text { VO-KA } \\
\text { Ljubljana }\end{array}$ & $\begin{array}{r}\text { Kleče, } \\
\text { Hrastje, } \\
\text { Šentvid, } \\
\text { Brest, } \\
\text { Jarški prod }\end{array}$ & $\begin{array}{l}\text { medzrnski } \\
\text { medzrnski } \\
\text { medzrnski } \\
\text { medzrnski } \\
\text { medzrnski }\end{array}$ & $\begin{array}{r}820 \\
400 \\
120 \\
130 \\
70\end{array}$ & 300.000 & 27,5 milijonov & $1100 \mathrm{~km}$ \\
\hline
\end{tabular}

\section{I. Varovanje kraških vodnih virov}

Ker so kraški vodonosniki zelo občutljivi na onesnaženje, zahtevajo kraški vodni viri ustrezno in previdno upravljanje. Postopki varovanja voda so predpisani v zakonodaji (Uradni list RS 67/02; Uradni list RS 64/04), vendar pa v njej posebnosti pretakanja vode v krasu, kot so vloga zaščitnih slojev, razvitost kraške mreže, spreminjanje zaledja v različnih hidroloških razmerah ipd., niso zadovoljivo upoštevane.

Pogosto se vodovarstvena območja določajo na podlagi skopih hidroloških in geoloških podatkov, redko pa so bile $\mathrm{v}$ te namene opravljene raziskave načina napajanja, pretakanja, skladiščenja in praznjenja kraških vodonosnikov ter izvedeni sledilni poskusi v zaledju vodnih virov, saj jih obstoječa zakonodaja ne predvideva. Pomanjkljivo je tudi izvajanje predpisanih ukrepov v praksi.

Za učinkovito varovanje najbolj občutljivih območij kraškega vodonosnika se v nekaterih evropskih državah pri določanju vodovarstvenih pasov uporablja koncept karti- 
ranja ranljivosti, pri načrtovanju rabe prostora na krasu pa v ospredje vse bolj stopa ocenjevanje tveganja za onesnaženje (Zwahlen 2004). Pri nas smo v ta namen razvili in preizkusili t.i. Slovenski pristop, metodo, ki upošteva posebnosti slovenskega krasa in je prilagojena slovenski zakonodaji (Ravbar in Goldscheider 2007).

\subsection{Odnos do pitne vode}

Ogrožena ni le kakovost voda, ampak tudi njene razpoložljive količine. Odkar je razširjena javna oskrba s pitno vodo, njena poraba narašča. Leta 2003 je bila izvedena obširna raziskava o odnosu posameznikov do pitne vode in značilnostih porabnikovih navad na območju jugozahodne Slovenije (Veljanovski in Ravbar 2005).

Študija je pokazala, da povprečen prebivalec obravnavanega območja porabi od 130 do 150 litrov vode na dan. Povprečna mesečna poraba vode v gospodinjstvih, zajetih v anketo, pa znaša $12 \mathrm{~m}^{3}$. Največje količine pitne vode, to je $1,4 \mathrm{~m}^{3}$ na mesec, posameznik porabi za splakovanje gospodinjskih in straniščnih odpadkov. Gospodinjstvo za umivanje in kopanje povprečno porabi $2,6 \mathrm{~m}^{3}$, za pranje posode in perila pa $2,2 \mathrm{~m}^{3}$ na mesec (Veljanovski in Ravbar 2005).

Pitna voda se uporablja tudi za čiščenje avtomobilov, zalivanje vrtov, v mestih pa za pranje ulic in drugih mestnih površin. Rezultati analize posameznikovih navad so pokazali, da devet od desetih vprašanih vedno zapira pipo, da ne teče po nepotrebnem. Ravno toliko se jih vedno tušira, namesto kopa. Polovica vprašanih vedno izbira varčni program pralnega stroja, vendar le tretjina izbira varčni program pomivalnega stroja. Le 35 odstotkov gospodinjstev ima nameščen obtežen plovec v straniščnem kotličku ali uporablja izmenični način izpiranja straniščne školjke. Kar 60 odstotkov vprašanih meni, da je poraba vode v njihovem gospodinjstvu sprejemljiva. Četrtina jih je zaskrbljenih, da porabijo zelo veliko vode, drugi pa menijo, da je poraba v njihovem gospodinjstvu majhna (Veljanovski in Ravbar 2005).

Analize anket kažejo, da cena vode ne vpliva odločilno na ravnanje s pitno vodo v posameznih gospodinjstvih. Če bi vodooskrbna podjetja uvedla dvojni cenovni režim za vodo, kakor je to $\mathrm{v}$ praksi uveljavljeno že pri električni energiji, bi večje porabnike vode $\mathrm{v}$ poceni terminih vključevala polovica vprašanih. Vsakemu petemu gospodinjstvu bi okoliščine vsakdana tega ne dopuščale, dobra četrtina gospodinjstev pa zaradi dvojnega cenovnega režima svojih navad ne bi spreminjala. Tudi če bi kazalo, da se bo strošek za vodo povečal za četrtino, kar 66 odstotkov vprašanih zaradi tega ne bi spreminjalo svojih navad, da bi $\mathrm{s}$ tem zmanjšali porabo vode v svojem domu. Znatno manjši delež naklonjenih varovanju okolja na ta način je zabeležil Smrekar (2005) v podobni raziskavi, opravljeni v mestnem in primestnem okolju Ljubljane.

\section{SKLEP}

V Sloveniji sta ohranjena narava in bogastvo ekosistemov 'samoumevna'. Prevladuje tudi prepričanje, da je območje naše države bogato z vodami, ne glede na njeno časovno in prostorsko razporeditev. Ogromni in številni kraški izviri, ki so skoraj vsi delno že zajeti za vodooskrbo, so na prvi pogled res neizčrpen vir kakovostne pitne vode. Ti pa lahko za- 
radi premajhne skrbi za ohranjanje naravnega in ekološkega ravnotežja ter malomarnega upravljanja kmalu postanejo neuporabni.

Zato je nujno potrebno, da ima država izdelano strategijo vodooskrbe, ne le vodovodov, temveč vsega sistema zbiranja in porabe vode, da bomo sebi in prihodnjim generacijam omogočili nadaljnjo nemoteno oskrbo s pitno vodo in ohranjali zadostne količine kakovostnih vodnih zalog brez negativnih posledic za okolje. Pri snovanju vodne oskrbe v prihodnosti je zato predvsem pomembna primerna zaščita vodnih virov, izvajanje predpisanih ukrepov v praksi in smotrna poraba vode.

\section{Viri in literatura}

Aledo Tur, A., Ortiz Noguera, G., Jeffrey, P., Gaerey, M., Rinaudo, J. D., Loubier, S., Veljanovski, T., Ravbar, N. 2006: Socio-cultural influences on water utilization: a comparative analysis. V: Koundouri, P., Karousakis, K., Assimacopoulos, D., Jeffrey, P., Lange, M. A. (ur.): Water management in arid and semi-arid regions, str. 201-225. Cheltenham, Northampton.

Andjelov, M., Gale, U., Kukar, N., Trišić, N., Uhan, J. 2006: Ocena količinskega stanja podzemnih voda v Sloveniji. Geologija 49, 2, 383-391. Ljubljana.

Brečko Grubar, V., Plut, D. 2001: Kakovost virov pitne vode v Sloveniji. Ujma 14-15, 238244. Ljubljana.

Bricelj, M., Rejec Brancelj, I. 1990: Oskrba z vodo v Koprskem primorju. Zbornik 15. zborovanja slovenskih geografov, str. 189-194. Ljubljana.

Kolbezen, M., Pristov, J. 1998: Površinski vodotoki in vodna bilanca Slovenije. Ministrstvo za okolje in prostor, Hidrometeorološki zavod RS. Ljubljana.

Petrič, M., Ravbar, N. 2008: Kraške vode so izjemno pomemben vir za vodooskrbo. V: Luthar, O. in sod. (ur.), Kras: trajnostni razvoj kraške pokrajine, str. 81-84. Ljubljana.

Pravilnik o kriterijih za določitev vodovarstvenega območja. Uradni list RS 64/2004. Ljubljana.

Ravbar, N., Kovačič, G. 2006: Karst water management in Slovenia in the frame of vulnerability mapping. Acta carsologica 35, 2, 73-82. Ljubljana.

Ravbar, N., Goldscheider, N. 2007: Proposed methodology of vulnerability and contamination risk mapping for the protection of karst aquifers in Slovenia. Acta carsologica 36, 3, 461-475, Ljubljana.

Richter-Jakob, B. 2005: Nachhaltigkeitsanalyse der Wasserver- und Abwasserentsorgungsstrukturen in städtischen Räumen: die Region Stuttgart. Stuttgarter Geographische Studien 136, 211 str., Stuttgart.

Smrekar, A. 2006: Zavest ljudi o pitni vodi. 166 str. Ljubljana.

Veljanovski, T., Ravbar, N. 2005: Socio-cultural determinants of drinking water consumption and the relation to it in south-western Slovene households. V: Mihevc, A. (ur.), Kras: water and life in a rocky landscape, str. 494-512. Ljubljana.

Zakon o vodah. Uradni list RS 67/2002. Ljubljana.

Zupančič, J. 1988: Oskrba z vodo ob suši v zahodni Suhi krajini. Geografski vestnik 60, 107-120. Ljubljana. 
Zwahlen, F. 2004: Vulnerability and risk mapping for the protection of carbonate (karstic) aquifers. Final report COST action 620, 297 str., European Commission, DirectorateGeneral for Research, Brüssel, Luxemburg.

\section{LOCAL DRINKING WATER SUPPLY IN KARST REGIONS}

\section{Summary}

Supply with adequate quantities of quality drinking water and lack of suitable cultivable land used to be the most restrictive factors of living and economic development in karst areas. In Slovenia, there are sufficient quantities of precipitation all year long, however, permeable limestone ground characteristisc of karst enable their fast infiltration and superficial waters are therefore rare. Water mainly flows underground and reappears on the surface at contact with impermeable rocks. Karst springs are usually abundant, of high quality and with stable discharge values all year round.

Consequently, commonly such springs used to be exploited already by the ancient inhabitants. To gain water from springs, people used to walk from remote areas for several kilometers. Springs were not only utilized as a primary source of drinking water, their energy was also used for mills, sawmills and smithies. On the vast karst plateaus where there are no surface waters, the main source of drinking water used to be gathering of rainwater, melting ice from ice caves, etc.

With the technological development, organized supply with drinking water gradually became more arranged and is today assured even to the most remote households. Modern water supply bases on capturing abundant springs and boreholes that drain water from vast karst aquifers. Evaluation of water sources in Slovenia show that about half of country's needs are covered by karst water sources, during dry period this percentage reach up to two thirds.

Despite very high importance of karst water sources, their protection is frequently insufficient. Sources of water supply are often organically polluted and threatened by accelerated urbanization, industrialization and accidental pollution. Usually protection against chemical contamination due to inappropriately built roads and dumping is not assured. Also the population, economic growth and numerous other socio-economic processes increase the need for drinking water while the attitude towards water is extremely careless and wasteful. These ascertainments have been confirmed by the detailed research on individual's behavior towards drinking water carried out in 2003. The main focus of the study was understanding the basic characteristics of the consumers' habits.

The study showed that an average inhabitant in SW Slovenia uses 130-150 1/day. The average monthly consumption of water in households was $12 \mathrm{~m}^{3}$. The biggest quantities of water (i.e., $1.4 \mathrm{~m}^{3} / \mathrm{month}$ ) were used for splashing. For hygienic purposes a household used $2.6 \mathrm{~m}^{3} /$ month and for washing the dishes and laundry $2.2 \mathrm{~m}^{3} /$ month. Unfortunately, drinking water is also used for cleaning cars and streets, and for irrigation.

The analysis results show that $60 \%$ of the asked think that the water consumption in their household is not big. A quarter of asked is worried that they use large quantities of water, 
all the rest believe that the consumption of water in their household is small. Nine out of ten individuals always close the tap, so that the water is not unnecessarily wasted. Nine out of ten also take shower instead of bath. However, the individual's attitude towards water is not always very economical. Only $35 \%$ of households have an alternating toilet splashing system. Only half of the asked always choose economic program of the dish washer and just a third chooses the economic program of the washing machine.

The analyses show that the prices of water do not crucially impact the attitude towards water in Slovene households. If the water supply companies would introduce a double pricing system for water as it is already in practice for electricity, only a half of asked would turn the biggest consumers on in the cheap terms. Every fifth household would not be able to do it due to other everyday tasks and a quarter of the households would not be prepared to change their habits. Even if the price of the water would rise for a quarter, $66 \%$ of the asked would not change their consumption attitude. However, two thirds of the asked is willing to pay more if the protection of water sources would be higher.

Droughts of the past years have been the warning that our state needs to have a comprehensive strategy of drinking water supply and consumption. To keep sufficient quantities of qualitative drinking water for our future generations, further planning of water supply will need to by based on appropriate protection of water sources, implementation on prescribed guidelines and economic consumption.

(Translated by the author) 